\title{
Effects of Chungkookjang Extract on Growth Hormone Secretion from GH3 Mouse Pituitary Cell and Growth Hormone Receptor Signaling Pathway
}

Sun \| Choi', Ji Eun Kim', In Sik Hwang', Hye Ryun Lee', Young Ju Lee' Hong Joo Son², Dong Seob Kim ${ }^{3}$ Kyu Min Park and Dae Youn Hwang'*

${ }^{1}$ Department of Biomaterial Science, ${ }^{2}$ Department of Life Science and Environmental Biochemistry, ${ }^{3}$ Department of Food Science and Technology, College of Natural Resources \& Life Science, Pusan National University, Miryang 627-706, Korea

${ }^{4}$ Jangmaeul Co, Miryang 627-882, Korea

Received August 7, 2012 /Revised September 20, 2012 /Accepted September 20, 2012

\begin{abstract}
The production and secretion of growth hormone $(\mathrm{GH})$ in the anterior pituitary gland can be induced by several natural products to control cell proliferation, differentiation, and migration. To investigate whether Chungkookjang (CKJ) produced by the fermentation process affects GH-related metabolism, the secretion and the response of GH were observed in pituitary cells and GH target cells. Among six CKJs manufactured by different strains of glycine max, only three CKJs, including Daewon (DW), Daepung (DP), and Taegwang (TG), induced GH secretion from GH3 cells at $5.0 \mathrm{mg} / \mathrm{ml}$ concentration. There were no significant changes detected in the viability of any of the cells treated with these CKJs. In addition, the increase in GH secretion from the GH3 cells was dependent on the concentration of the three types of CKJs. The proliferation of cell lines, including MG63 and HepG2 cells, that originated from those derived from the GH target organs was significantly activated by treatment with the GH-containing conditional medium (GCM) harvested from the three CKJ-treated GH3 cells, although their induction rate was different from each other. In these cells, p-STAT5 was maximally translocated into the nucleus of MG63 cells 30 min after DW treatment, while it was translocated in HepG2 cells at $60 \mathrm{~min}$. These results suggest that these three types of CKJ could enhance the secretion of GH, as well as the GCM-derived response, in the two target organs.
\end{abstract}

Key words : Chungkookjang (CKJ), growth hormone (GH)

\section{서 론}

우수한 단백질 급원인 콩(Glycine max)은 각종 성인병의 원 인이 되는 혈중 콜레스테롤을 낮추어 동맥경화, 고혈압 등의 예방과 당뇨병, 간장병에 탁월한 효과와 항암작용을 한다고 보고되어있으며[23], 특히 isoflavones의 함량이 높은 콩 단백 질은 성장호르몬의 분비를 촉진시켜, 척추골밀도와 대퇴골밀 도 향상을 유리하게 한다[1]. 이러한 콩을 원료로 한 대표적인 발효식품 중의 하나인 청국장은 영양적으로 우수할 뿐만 아니 라, 여러 가지의 생리활성기능을 나타내는 것으로 알려졌다 [20]. 청국장 발효과정 중에서 콩 속에 함유된 isoflavone, phytic acid, saponin, trypsin inhibitor, tocopherol, lignin, vi$\operatorname{tamin} \mathrm{E}$ 와 $\mathrm{K}$, 불포화지방산, 식이섬유, 인지질 및 올리고당 등의 각종 생리활성물질을 다량으로 함유 하고 있어, 기능성 식품소재로서의 이용 가능성이 재조명 되고 있다[15,16,17,19].

청국장은 발효과정에서 생성된 생리활성물질이 항암성[10] 과 면역기능개선[20], 지질대사 개선효과[31], 심장병 예방 및 콜레스테롤 저감효과[2,25], 혈압상승 억제효과로 인한 고혈압

*Corresponding author Tel : +82-55-350-5388, Fax : +82-55-350-5389

E-mail : dyhwang@pusan.ac.kr
예방[18], 골다공증 예방 또는 치료[12,28], 항돌연병이성 및 항균작용 등의 기능을 나타낸다. 청국장의 만성질환에 미치는 효능 연구는 활발하게 보고되고 있으나, 세포의 성장과 분화 와 관계된 효능과 작용기전에 대한 연구는 미비한 실정이다.

따라서 본 연구는 청국장이 생리활성기능으로서 뇌하수체 세포주로부터 성장호르몬 분비 및 미분화 세포에서 성장호르 몬 수용체의 신호전달에 미치는 영향을 분석하고자 하였다. 그 결과 6가지 청국장 추출물 중에서 성장호르몬 분비를 촉진 시키는 청국장 추출물의 종류를 선별하였고, 분비된 성장호르 몬이 표적세포의 신호전달에 미치는 영향을 규명하였다.

\section{재료 및 방법}

\section{실험재료}

본 실험에서는 청국장 제조에 많이 사용되는 6가지 콩 품종 (strain)인 풍산(Pungsan, PS), 풍원(Pungwon, $\mathrm{PW})$, 대원 (Daewon, DW), 대풍(Daepung, DP), 태광(Taegwang TG), 신화 (Shinhwa, SH)을 사용하였으며, 이들은 국립식량과학원 (Miryang, Korea)에서 공급받았다. 청국장 발효에 사용되는 Bacillus subtilis 균주는 부산대학교 응용 및 환경미생물학 연구 실에서 공급받아, $37^{\circ} \mathrm{C}$ 에서 24 시간 전배양하여 준비하였다. 
콩 $(100 \mathrm{~g})$ 은 고압 멸균기를 이용하여 $121^{\circ} \mathrm{C}$ 에서 30 분 동안 증 자한 후, $37^{\circ} \mathrm{C}$ 로 냉각하였다. 배양된 Bacillus subtilis 종균액을 멸균된 콩에 $5 \%(\mathrm{w} / \mathrm{w})$ 로 접종하고 $\left(1 \times 10^{9} \mathrm{cells} / \mathrm{ml}\right), 37^{\circ} \mathrm{C}$ 배양 기(JSSI-200CL, JSR, Victoria, Australia)에서 48시간 동안 발효 시켰다. 발효 청국장을 동결건조 및 균질화 한 후, $5 \mathrm{~g}$ 을 증류 수 $50 \mathrm{ml}$ 에 첨가하여 $30^{\circ} \mathrm{C}, 200 \mathrm{rpm}$ 에서 2시간 동안 진탕하였 다. 청국장 잔여물을 제거하기 위하여 원심분리 $(1,000 \mathrm{rpm}, 20$ 분) 및 여과 $(0.45 \mu \mathrm{m})$ 한 후, 상등액을 다시 동결건조 하였다. 이 추출물은 멸균수에 희석하여 $0.63,1.25,2.50,5.00 \mathrm{mg} / \mathrm{ml}$ 농도로 준비하였다.

\section{세포배양}

청국장의 세포독성, 성장호르몬 분비능과 성장호르몬 수용 체 신호전달을 연구하기 위하여 사용된 GH3, MG63, HepG2 세포주는 한국세포주은행(Korean Cellline Bank, Korea)에서 구입하여 사용하였다. 쥐의 뇌하수체 종양으로부터 유래한 $\mathrm{GH} 3$ 세포주는 성장호르몬과 유즙분비호르몬을 분비하는 세 포주로서 호르몬의 분비기전, 신호전달 기전, 소마토스타틴 수용체 등의 발현의 조절기전의 연구에 주로 사용된다[27]. $\mathrm{GH} 3$ 세포주는 10\% fetal bovine serum (FBS) (Gibco, Carlsbad, CA, USA), L-glutamine, penicillin 및 streptomycin (Cambrex, NJ, USA)을 함유한 Dulbecco's modified Eagle medium (DMEM, Gibco)에 $37^{\circ} \mathrm{C}, 5 \% \mathrm{CO}_{2}$ 조건의 incubator에 서 배양하였다. MG63 세포주는 사람 골육종에서 유래된 세포 로서 $10 \%$ 의 열처리된 $\mathrm{FBS}$ 와 penicillin/streptomycine 이 함 유된 DMEM복합 배지로 동일한 조건에서 배양하였다. Human hepatocytes인 HepG2 세포주는 $10 \%$ 의 열처리된 FBS 와 penicillin/streptomycine 이 함유된 Minimum Essential Medium (Gibco) 복합배지로 동일한 조건에서 배양하였다.

\section{MTT 분석}

MTT (3-[4,5-Dimethylthiazol-2-yl]-2,5-diohenyl tetrazolium bromide, Sigma Chemical Co., USA)는 살아있는 세포 내 미토콘드리아 내막에 존재하는 oxido-reductase의 효소 작 용에 의해 환원되어 보라색의 formazan을 형성하게 되는데, 용해액 내 보라색 formazan의 발색정도를 흡광도로 측정함으 로써 세포 생존률을 예측하는 실험방법으로 이용되고 있다[8]. 먼저 GH3, MG63과 HepG2 cell을 96 well (3x10 세포/well) 에 분주하여 24시간 배양한 뒤, 증류수(Vehicle), 청국장을 농 도별로 처리하고, 3시간 동안을 배양하였다. 배양용 배지를 제거하고, MTT용액을 $50 \mathrm{\mu l}$ 첨가한 뒤, 4 시간 동안 추가 배양 하였다. 세포 내에 보라색 결정이 생성되면 Dimethly sulphoxide (DMSO) (Sigma Chemical Co.) 용액을 150 씨씩 넣고, formazan을 녹였다. 각 well에 나타난 색깔의 변화를 ELISA-reader (VERSA max, micro-reader, MDS. Co, USA)를 이용하여 $540 \mathrm{~nm}$ 에서 측정하였다.

\section{Dot Blot 분석}

청국장이 GH3 세포주로부터 성장호르몬 분비에 미치는 영 향을 단백질 수준으로 확인하기 위해, 먼저, GH3 세포주를 serum-free media로 밤새 배양 후, 다양한 농도와 품종별로 청국장 추출물을 $\mathrm{GH} 3$ 세포주에 처리하고, 24시간 배양한 배 양액을 채취하여, Slot Blot analysis를 이용하여 측정하였다. 먼저 성장호르몬이 포함된 세포 배양액은 Slot Blot kit (Pharmacia Biotech, CA, USA)를 이용하여 nitrocelulose membrane에 전이시켰다. Membrane은 1시간 동안 실온에서 $5 \%$ Skim milk로 블로킹 한 후, 일차 항체인 rabbit polyclonal anti-GH antibody (Santa Cruz biotechnology Inc., CA, USA) 로 1 시간 동안 처리하였다. 그리고 이차항체인 horseradish peroxidase conjugated goat anti-rabbit IgG (GenTest, MA)를 실온에서 1시간 처리하였으며, ECL Kit를 이용하여 발광 정도 를 확인하였다.

\section{MG63과 HepG2 세포주에서 성장과 분화 효과}

$\mathrm{GH} 3$ 세포주에서 분비되는 성장호르몬이 골아세포와 간세 포의 성장과 분화를 유도하는지를 평가하기 위하여, 조건적 배양액(Conditional medium, $\mathrm{CM}$ )을 이용한 세포분화능을 측 정하였다. 이를 위해, 먼저 $\mathrm{GH} 3$ 세포주를 serum-free media로 밤새 배양 후, 청국장 추출물을 품종과 농도별로 처리하여 3시 간 배양한 뒤, 성장호르몬이 분비된 조건적 배양액을 확보하 였다. 이들 배양액은 MG63과 HepG2 세포주에 처리하여 시간 의 경과에 따른 세포주의 분화를 위상차 도립 현미경(Leica Microsystems, Switzerland)를 이용하여 관찰하였다.

\section{면역형광염색(Immunofluorescence)}

세포에서 성장호르몬 수용체 신호전달과정의 변화를 관찰 하기 위하여, 면역형광염색을 통하여 분석하였다. 이를 위해, MG63과 HepG2 세포는 성장호르몬이 분비된 조건적 배양액 에서 3시간 동안 배양한 후 $4 \%$ Formaldehyde (Junsei Chemical Co., Japan)로 1시간동안 고정시키고, $0.1 \%$ Triton X-100을 5분 처리하여, permeabilization하였다. 그리고 $0.5 \%$ $\mathrm{BSA}$ 로 1시간 동안 블로킹한 다음, anti-signal transducers and activators of transcription (STAT) 5 antibody (Abcam, Cambridge, UK), anti-p-STAT5 antibody (Abcam) 1차 항체 로 $4^{\circ} \mathrm{C}$ 에서 밤새 결합시킨 후, FITC-conjugated된 secondary antibody와 4',6-diamidino-2-phenylindole (DAPI)를 첨가한 후 형광현미경(Olympus IX71, Hamburg, Germany)을 이용 해 단백질의 발현을 관찰하였다.

\section{통계분석}

청국장 추출물 처리군과 Vehicle 처리군의 세포간 실험 결 과에 대한 유의성은 One way ANOVA (SPSS for Windows, Release 10.10, Standard Version, USA)를 이용하여 분석하였 
고, P-value $<0.05$ 를 유의성이 있는 값으로 인정하였으며, 실험 결과는 means $\pm \mathrm{SD}$ 로 제시하였다.

\section{결 과}

뇌하수체 전엽 세포의 생존율과 성장호르몬 분비에 미치는 청국장의 품종의 영향

청국장의 6가지 추출물 중에서 뇌하수체 전엽 세포의 생존 과 성장호르몬 분비에 미치는 영향을 평가하기 위하여, $\mathrm{GH} 3$ 세포주에 6가지(풍산, 풍원, 대원, 대풍, 태광, 신화) 청국장 추 출물을 $2.5 \mathrm{mg} / \mathrm{ml}$ 의 농도로 3시간 처리한 후, 세포 생존율과 성장호르몬의 분비량을 측정하였다. 그 결과, 세포생존율은 풍산 청국장 추출물을 처리한 그룹에서 $20 \%$ 증가하였고, 이를 제외한 나머지 모든 그룹에서는 유의성 있는 변화를 나타내지 않았다(Fig. 1A). 그러나 성장호르몬의 분비량은 대원, 대풍, 태광 추출물을 처리한 그룹에서 Vehicle 처리군보다 높았으 며, 다른 품종의 청국장 추출물을 처리한 그룹에서는 Vehicle 처리군과 유사한 수준의 성장호르몬이 분비되었다(Fig. 1B). 따라서 이러한 실험 결과는 청국장의 6가지 추출물은 뇌하수 체 전엽 세포에 독성이 없으며, 대원, 대풍, 태광 품종의 청국 장 추출물이 유의적으로 성장호르몬의 분비를 촉진함을 제시 하고 있다.

청국장 추출물의 농도 변화에 따른 뇌하수체 전엽 세포 생 존율과 성장호르몬 분비 영향

뇌하수체 전엽 세포의 생존과 성장호르몬 분비에 미치는 청국장의 3 가지 추출물의 농도 의존적 영향을 평가하기 위하 여, 3 가지 청국장 품종의 추출물을 처리한 후, 세포 생존율과 성장호르몬 농도를 분석하였다. 그 결과 세포 생존율은 3 가지 청국장 추출물이 대조군에 비하여 $5.0 \mathrm{mg} / \mathrm{ml}$ 의 농도로 처리 하였을 때만 유의적으로 증가하였다(Fig. 2A). 그러나, 성장호 르몬의 분비량은 대원, 대풍 추출물의 경우, $2.5,5.0 \mathrm{mg} / \mathrm{ml}$ 로 처리한 그룹에서 Vehicle 처리군 보다 증가하였으며(Fig. 2B), 태광 추출물의 경우 $5.0 \mathrm{mg} / \mathrm{ml}$ 을 처리한 그룹에서만 증가하 였다. 이러한 결과는 청국장 추출물은 세포생존율과 성장호르 몬 분비를 농도의존적으로 유도할 수 있음을 제시하고 있다.

청국장에 의해 분비된 성장호르몬이 골아세포의 분화에 미 치는 영향

또한, 분비된 성장호르몬이 실제로 세포의 분화와 성장을 촉진시키는 지를 확인하고자, 3 가지 종류의 청국장 추출물을 처리하여 분비된 성장호르몬이 포함된 조건적 배양액에서 MG63 세포를 배양하여 세포의 성장을 관찰하였다. 그 결과, MG63 세포의 성장은 대원과 대풍 청국장 추출물의 조건적 배양액을 처리한 그룹에서 농도의존적으로 대조군에 비하여 증가되었다. 그러나 대풍 청국장 추출물의 조건적 배양액을
A

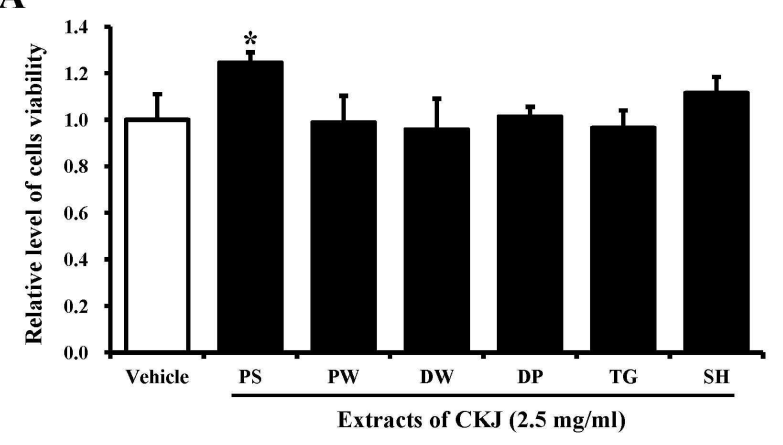

B
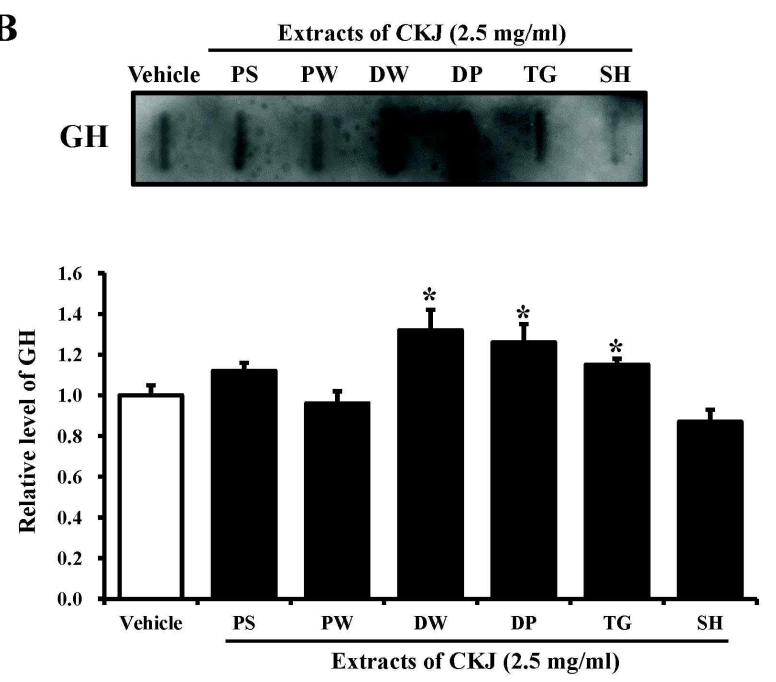

Fig. 1. Effects of CKJ manufactured by six different strains of glycine max on cytotoxicity and GH secretion ability of GH3 cells. After treatment of CKJ extract for 24 hrs, the viability of GH3 cells was measured using MTT assays (A). GH concentration in the supernatant was measured using a dot blot assay (B). The values of data represented the means \pm SD of three experiments. ${ }^{*} p<0.05$ is the significance level relative to the vehicle-treated group.

처리한 경우에는 농도에 상관없이 일정한 성장을 나타내었다 (Fig. 3). 이러한 결과는 대원과 대풍 청국장 추출물의 처리로 분비된 성장호르몬이 농도의존적 반응을 나타내며, 세포 성장 을 촉진 시킴을 제시하고 있다.

청국장에 의해 분비된 성장호르몬이 골아세포의 성장호르몬 수용체의 신호전달에 미치는 영향

분비된 성장호르몬이 성장호르몬 수용체의 신호전달에 미 치는 영향을 관찰하고자, 대원 추출물 $5 \mathrm{mg} / \mathrm{ml}$ 의 농도로 처 리로 얻어진 조건적 배양액에서 골아세포인 MG63 세포를 배양하고, STAT5와 p-STAT5 발현을 면역형광염색을 통해 분석하였다. 그 결과, STAT5는 대원 청국장 추출물의 조건적 배양액을 처리한 MG63세포에서 15분부터 60분까지 세포질 에서 강하게 관찰되었으나(Fig. $4 \mathrm{~A}$ ), p-STAT5는 30 분에 핵에 
A

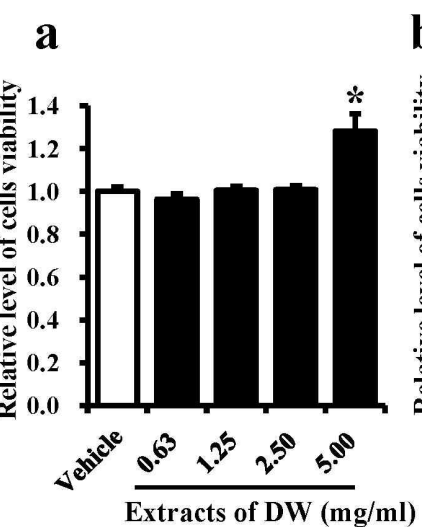

b

c
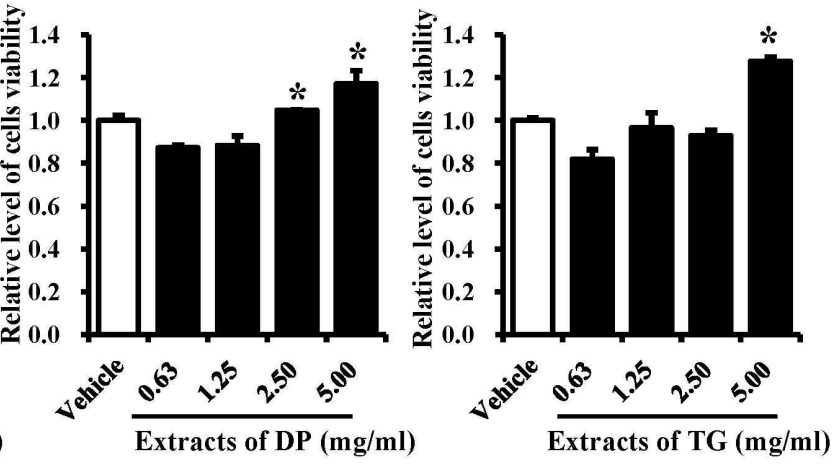

B

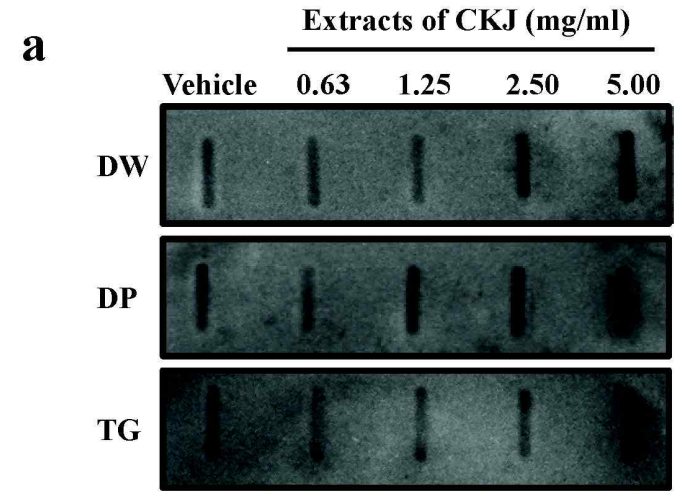

b

c

d
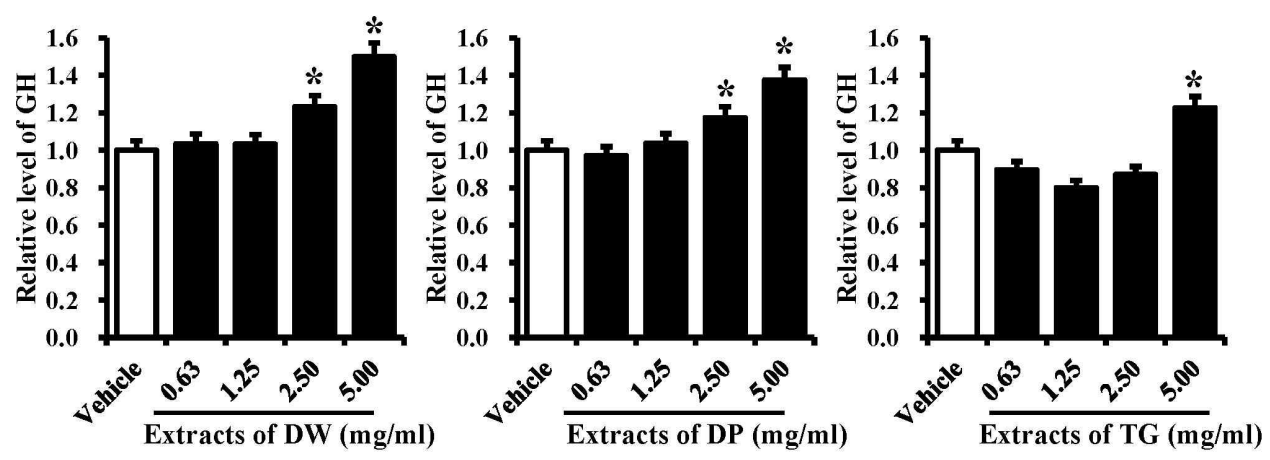

Fig. 2. Dose dependent effects of CKJ manufactured by three different strains of glycine max (DW, DP, TG) on cytotoxicity and GH secretion ability. The viability of GH3 cells were measured using MTT assays after treatment of CKJ extract (A). The culture supernatants were collected from cells of each group. GH concentration in the supernatant was measured using dot blot assay (B). The values of data represented the means \pm SD of three experiments. ${ }^{*} p<0.05$ is the significance level relative to the vehicle-treated group.

서 가장 높은 발현을 나타낸 이후 60 분에 점진적으로 감소되 었다(Fig. $4 \mathrm{~B})$. 이러한 결과는 대원 청국장 추출물의 조건적 배양액은 골아 세포에서 성장호르몬 신호전달과정을 자극하 여 STAT 인산화와 핵 내로의 이동을 촉진시킴을 제시하고 있다.
청국장에 의해 분비된 성장호르몬이 간세포의 분화에 미치 는 영향

청국장에 의해 분비된 성장호르몬이 간세포주의 분화에 미치는 영향을 분석하기 위하여, 성장호르몬 수용체를 발현 하는 간세포주인 HepG2에 성장호르몬이 포함된 조건적 배 
A
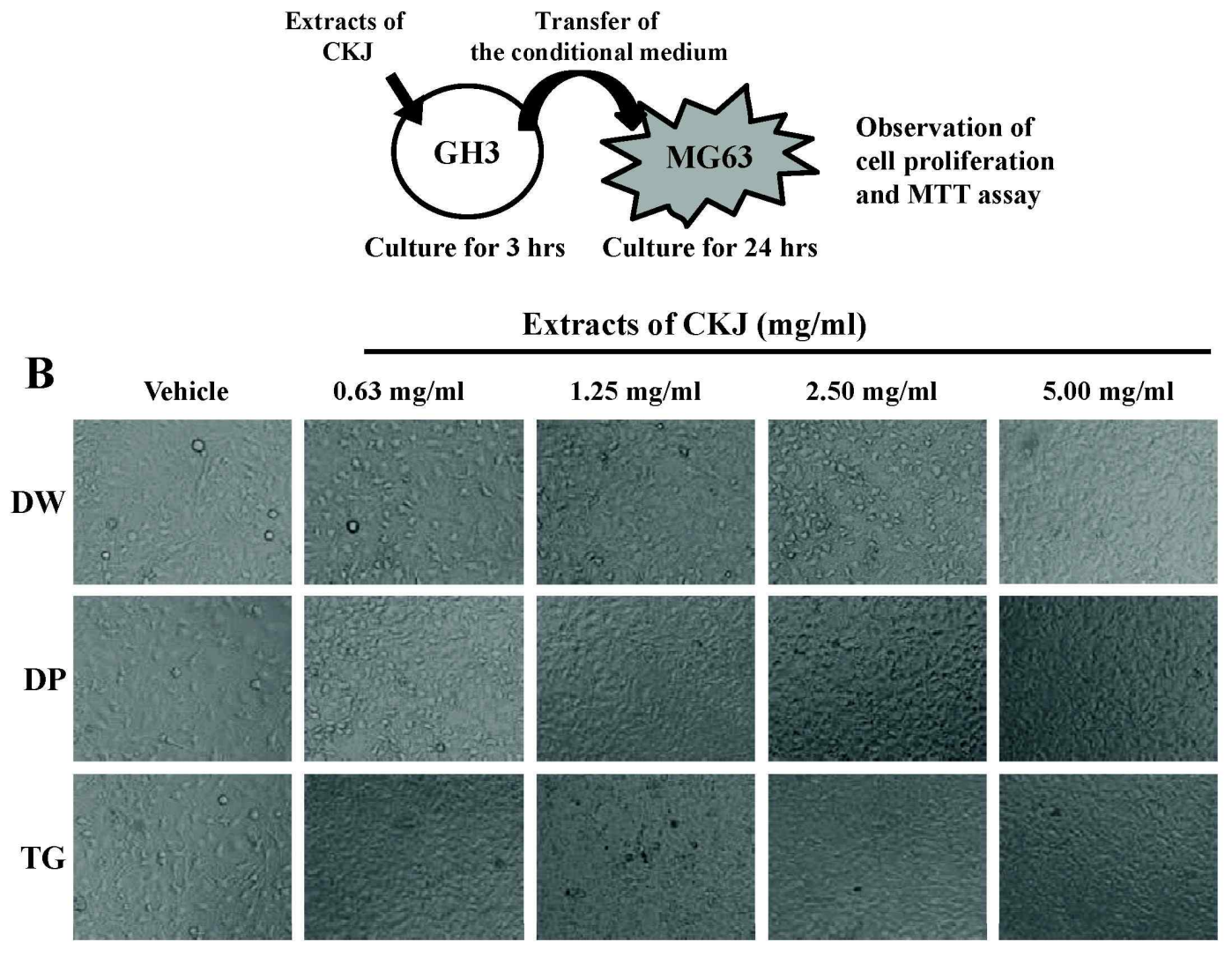

C a

b

c

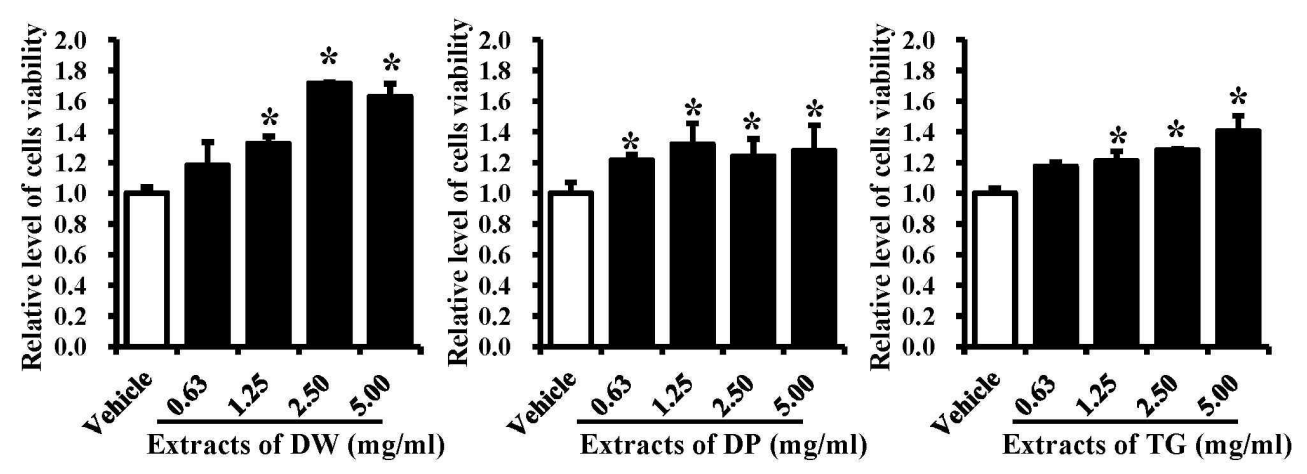

Fig. 3. Microscope images and proliferation of MG63 cells. After three type extracts of CKJ treatment during 3 hrs, the conditional medium was collected from GH3. And then MG63 cell was incubated with this media for $24 \mathrm{hrs}$ (A). Cellular morphology of MG63 cells was observed at 10x magnification (B). Activity of cell viability was measured via MTT assays (C). The values of data represented the means \pm SD of three experiments. ${ }^{*} p<0.05$ is the significance level relative to the vehicle-treated group.

양액을 처리 한 후, 성장을 관찰하였다. 그 결과 대원과 대 풍 청국장 추출물의 조건적 배양액을 처리한 그룹에서는 농 도 의존적으로 세포성장이 증가하였으나, 태광 청국장 추출 물의 조건적 배양액을 처리한 그룹에서는 $2.5 \mathrm{mg} / \mathrm{ml}$ 처리 한 세포에서만 약간의 세포성장 증가를 나타내었다(Fig. 5). 이러한 결과는 대원과 대풍 청국장 추출물의 조건적 배양액
이 간세포주의 성장을 촉진 시키는 효과가 있음을 제시하고 있다.

청국장에 의해 분비된 성장호르몬이 간세포의 STAT5의 인산화에 미치는 영향

또한 분비된 성장호르몬이 간세포에서 STAT5의 인산화에 
A

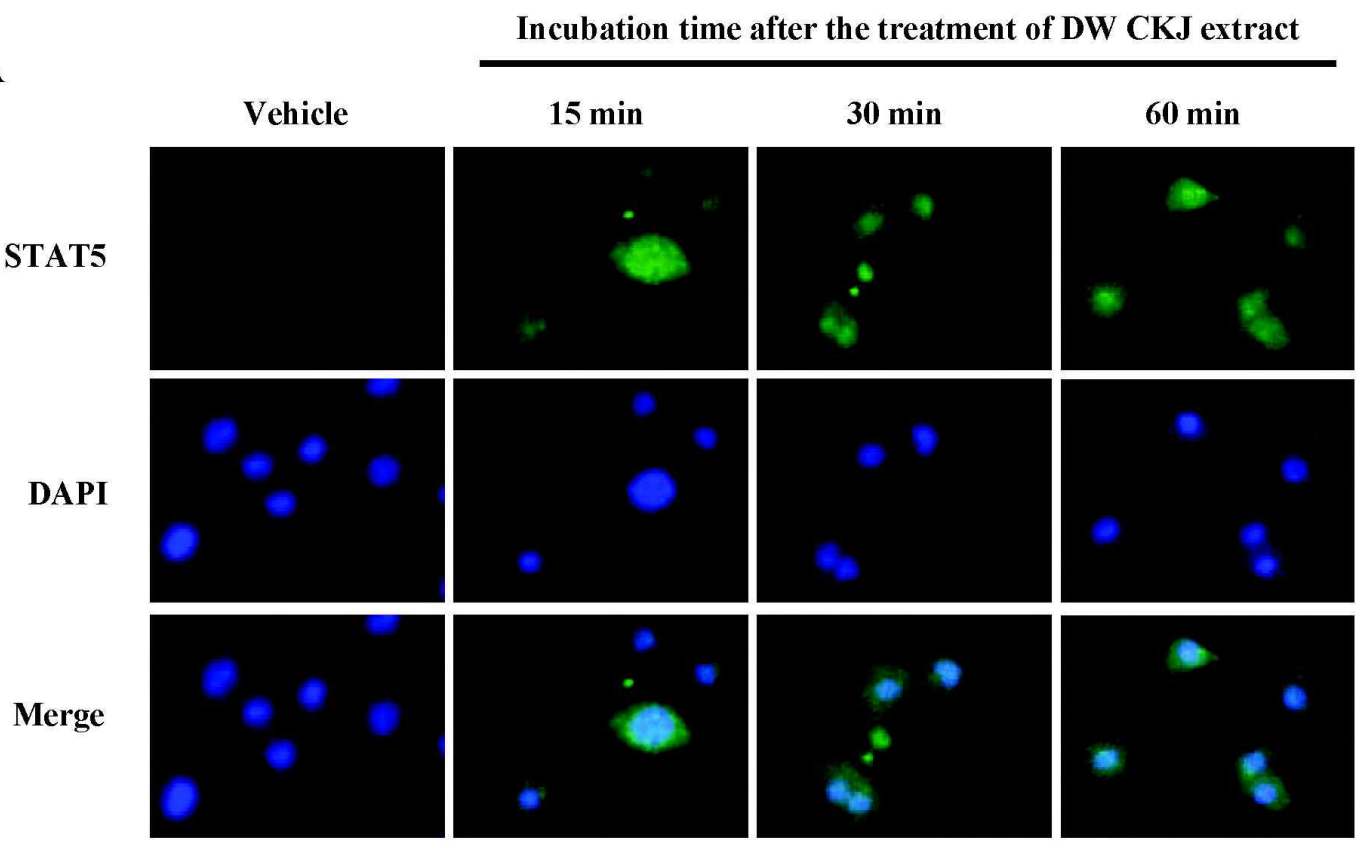

B

Incubation time after the treatment of DW CKJ extract

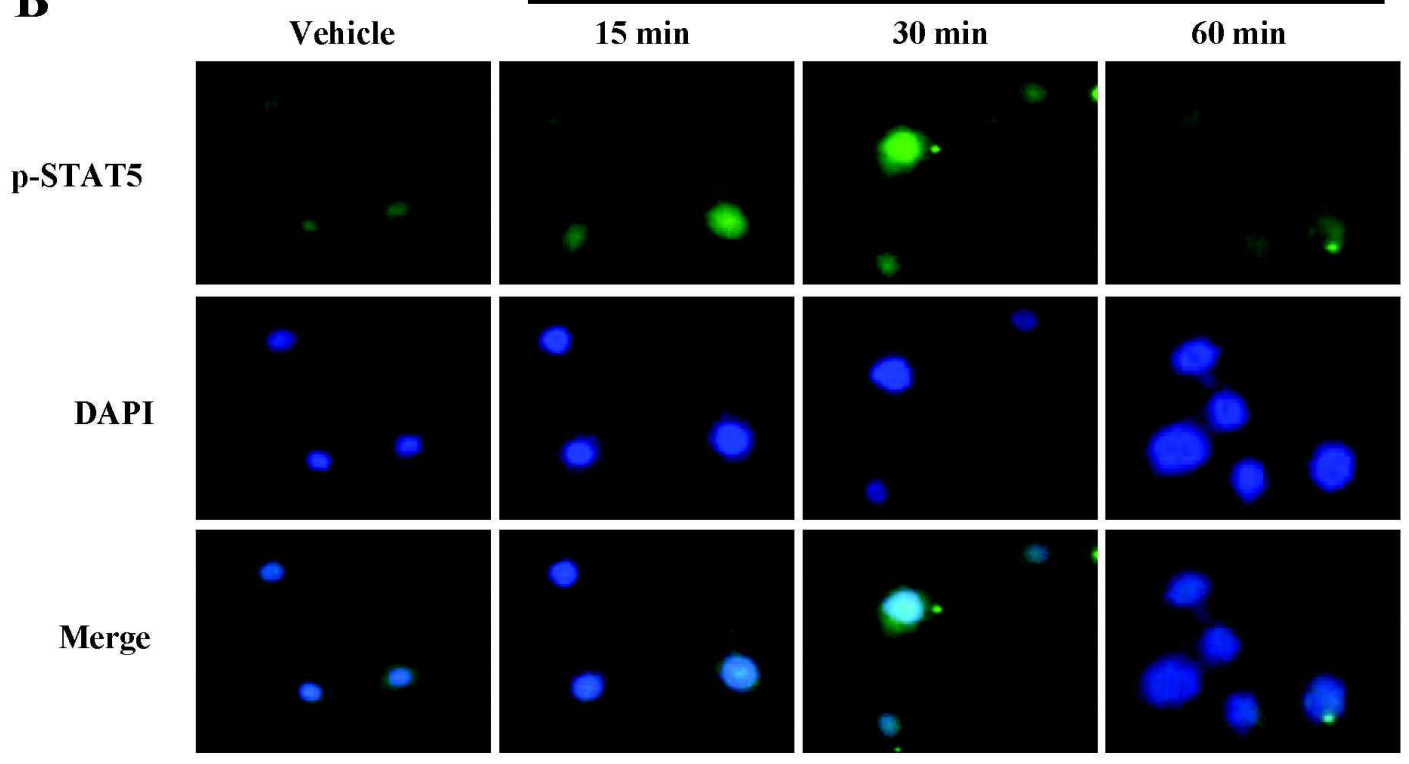

Fig. 4. Immunofluorescence images of STAT5 and p-STAT5 in MG63 cells. MG63 cells treated with $2.5 \mathrm{mg} / \mathrm{ml}$ of DW CKJ extract during incubated time and then fixed with $4 \%$ formaldehyde and stained. STAT5 and p-STAT5 was stained using with a specific antibody following a secondary antibody coupled to Fluorescein. Also, cells were stained with DAPI in order to detect nucleus changes. The cellular morphology was observed under a fluorescent microscope (original magnification $\mathrm{x} 40)$.

미치는 영향에 대해 살펴보고자, 분화 효과가 가장 좋았던 대 원 청국장 추출물을 $5 \mathrm{mg} / \mathrm{ml}$ 의 농도로 처리하여 면역형광염 색을 통해 분석하였다. 그 결과, STAT5는 대원 청국장 추출물 의 조건적 배양액 처리한 HepG2세포에서 대조군 보다 30분 이후부터 세포질에서 발현이 지속되었으며(Fig. 6A), p-STAT5
는 60 분에 핵에서 가장 발현이 두드러졌다(Fig. 6B). 이러한 결과는 대원 청국장 추출물의 조건적 배양액이 간세포에서 성장호르몬 신호전달과정을 자극하여 STAT 인산화와 핵 내 로의 이동을 촉진시킴을 제시하고 있다. 
A
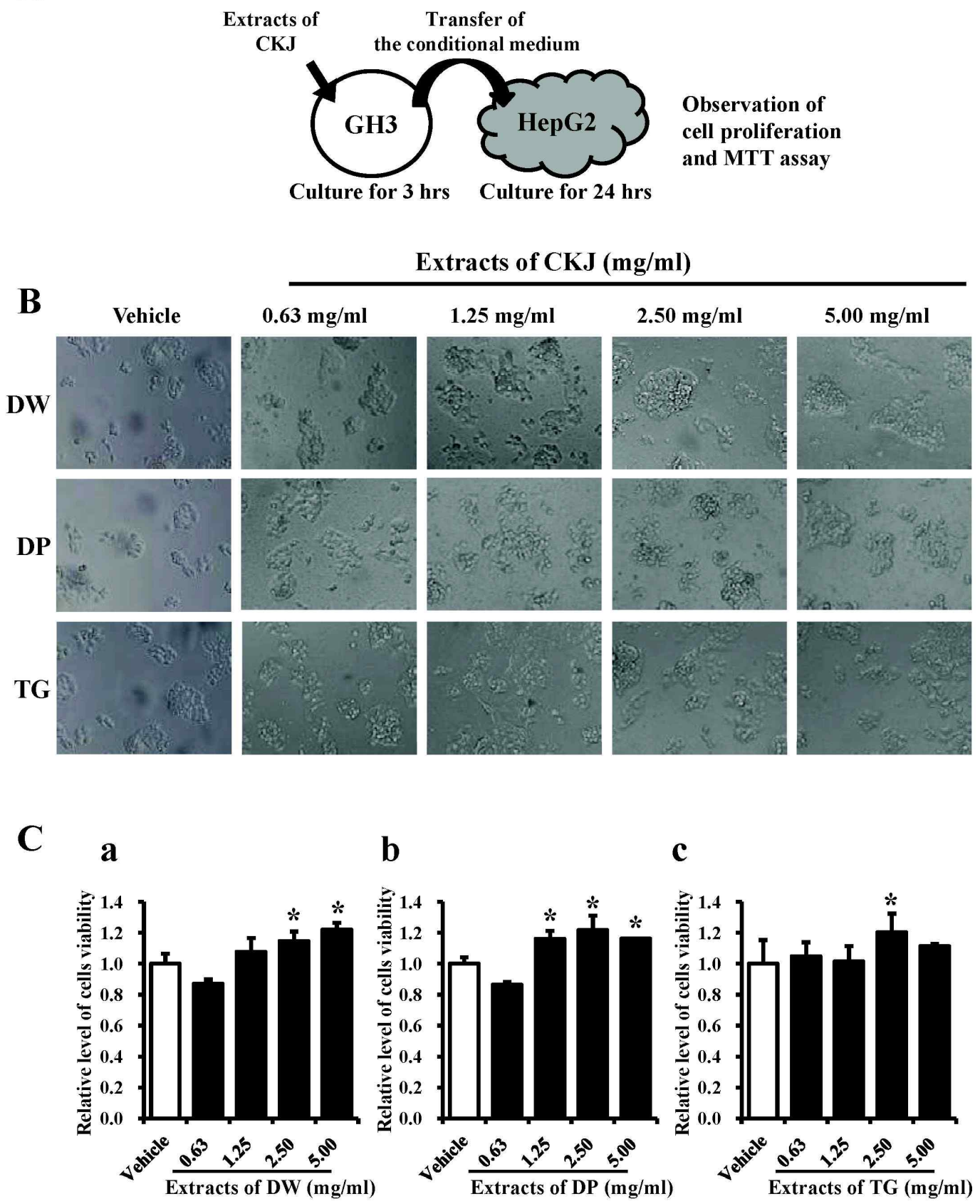

Fig. 5. Microscope images and proliferation of HepG2 cells. After three type extracts of CKJ treatment during 3 hrs, the conditional medium was collected from GH3. And then HepG2 cell was incubated with this media for 24 hrs (A). Cellular morphology of MG63 cells was observed at 10x magnification (B). Activity of cell viability was measured via MTT assays (C). The values of data represented the means $\pm \mathrm{SD}$ of three experiments. ${ }^{*} \not 0.05$ is the significance level relative to the vehicle-treated group.

\section{고 찰}

성장호르몬은 뇌하수체 전엽에서 분비되며, 191개의 아미 노산으로 구성된 단일 폴리펩티드 호르몬이다[23]. 성장호르 몬은 직접적으로 성장판의 연골세포 분화를 자극하여 성장을 촉진시키기 때문에, 어린이의 정상적인 성장에 중요한 역할을
한다[3]. 또한 이 호르몬은 아미노산의 세포 내 유입을 촉진하 고, 단백질 분해를 억제하며 단백질 합성과 축적을 증가시키 는 역할을 하고, 인슐린과 길항작용을 하여 글리코겐 분해작 용, 당 신생성 등을 증가시켜 탄수화물 대사 작용이나 지방분 해 등의 지질의 대사작용에 영향을 주어, 성인의 대사를 조절 한다[3,14,31]. 이러한 성장호르몬은 여러 말초조직에 위치하 
A

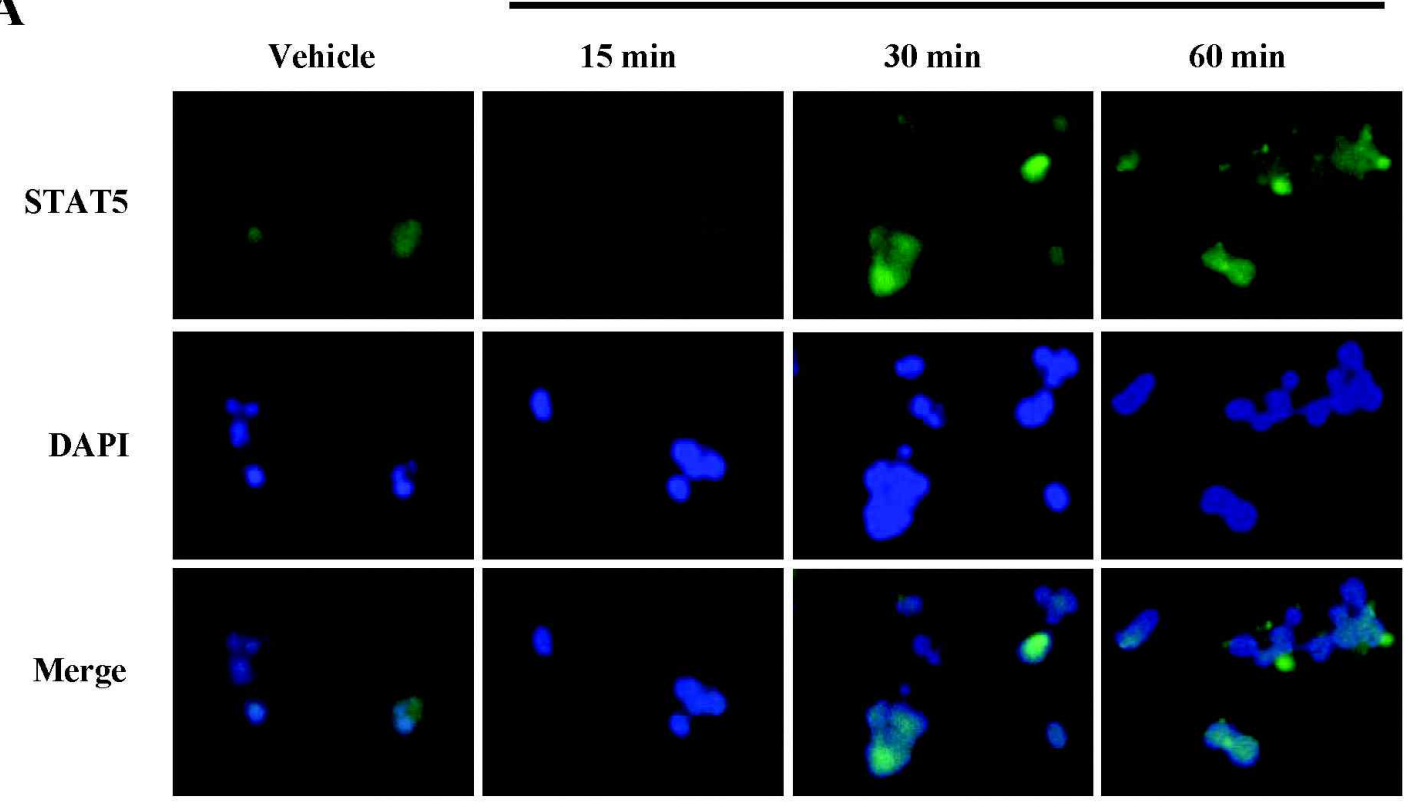

B

Incubation time after the treatment of DW CKJ extract

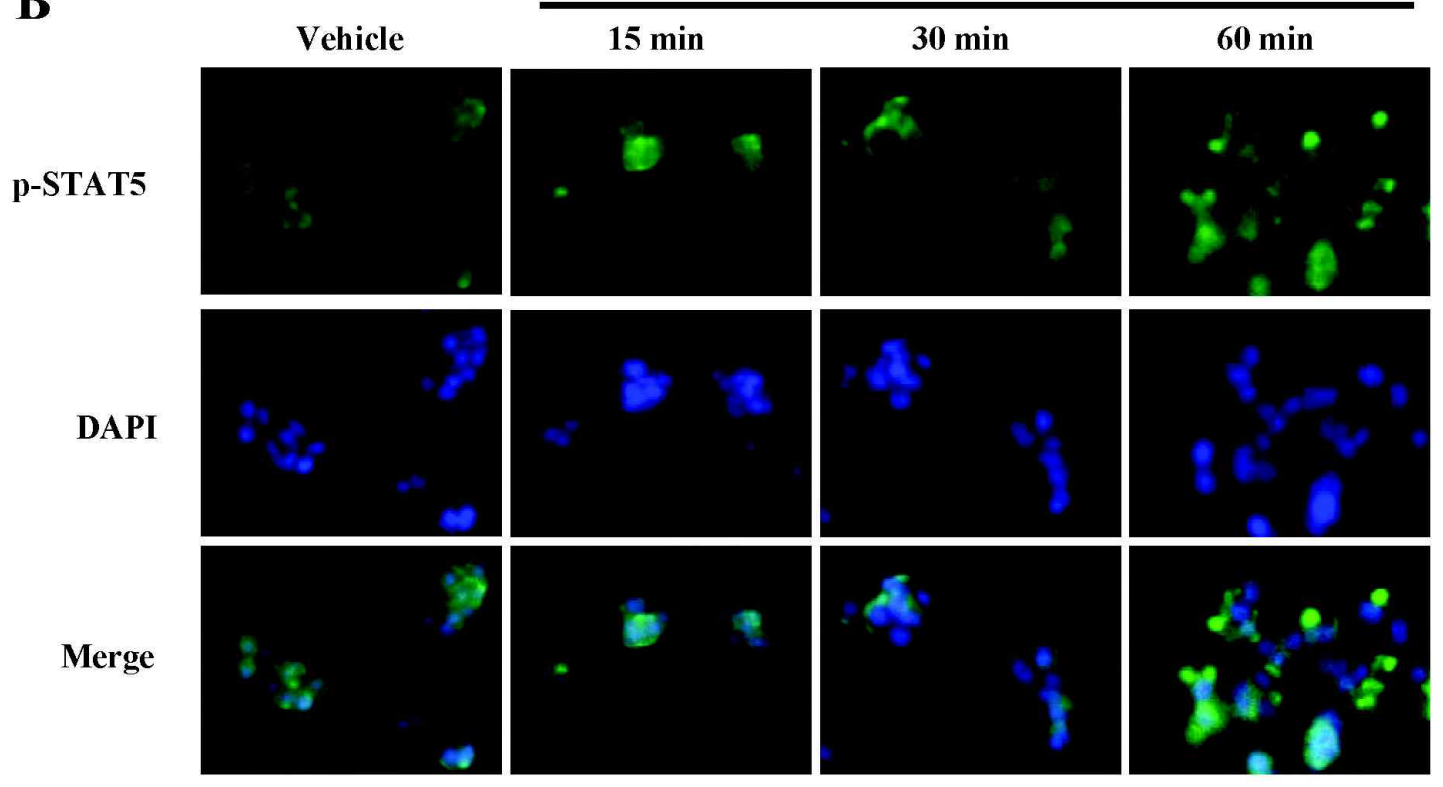

Fig. 6. Immunofluorescence images of STAT5 and p-STAT5 in HepG2 cells. HepG2 cells treated with $2.5 \mathrm{mg} / \mathrm{ml}$ of DW CKJ extract during incubated time and then fixed with $4 \%$ formaldehyde and stained. STAT5 and p-STAT5 was stained using with a specific antibody following a secondary antibody coupled to Fluorescein. Also, cells were stained with DAPI in order to detect nucleus changes. The cellular morphology was observed under a fluorescent microscope (original magnification $x 40)$.

는 성장호르몬 수용체와 결합하여 Janus kinase2 (JAK2)와 STAT를 통해 성장과 대사작용을 조절한다[5,9]. 따라서, 성장 호르몬의 분비와 성장호르몬 수용체 신호전달과정을 촉진하 는 새로운 물질을 검색하고, 그 작용기전을 분석하는 연구는
매우 중요하게 평가되고 있다.

최근까지 성장호르몬의 분비를 촉진하는 물질로는 Fenugreek (Trigonella foenum-graecum L.), Panax ginseng C. A. Meyer (Ginseng) 등이 알려져 있다[29,32]. Fenugreek 씨앗의 
메탄올 추출물의 중에서 saponin I과 dioscin은 랫드의 뇌하수 체 전엽세포의 성장호르몬 분비를 12-17배정도 증가시켰다 [29]. 또한 ginseng은 랫드의 뇌와 뇌하수체에서 성장호르몬 유전자의 발현과 성장호르몬의 분비량 증가를 유도하였다 [32]. 본 연구에서는 비록 유전자의 발현을 관찰하지 못하였지 만, 청국장 추출물이 뇌하수체 세포로부터 성장호르몬 분비를 촉진함을 보여주고 있어, fenugreek와 ginseng과 유사한 효과 를 나타냄을 제시하고 있다.

한편, 콩과 이소플라본에 의한 호르몬 분비 촉진에 관한 연 구도 보고되었다. Iodine의 결핍을 유도한 랫드에 콩이 많이 함유된 식이를 12 주 동안 투여하면, 갑상선 자극호르몬 (thyroid stimulating hormone, TSH), 프로락틴(proractin, $\mathrm{PRL})$, 성장호르몬을 분비하는 세포가 증가되었으며, 이러한 증가는 이들 호르몬 유전자의 발현과 관련 있는 뇌하수체 전 사인자-1 (pituaitary transcription factor-1, Pit-1)의 발현과 밀 접한 연관이 있는 것으로 알려져 있다[13]. 또한 15살 된 건강 한 여성이 9달 동안 $45 \mathrm{mg}$ 의 conjugated isoflavones을 섭취하였 을 때, 황체형성호르몬(luteinizing hormone, LH)과 난포자극 호르몬(follicle stimulating hormone, FSH)의 Mid-cycle peak 는 억제되지만, 스테로이드계 성호르몬에는 변화를 유발하지 못하였다. 그러나 전체 콜레스테롤의 양은 유의적으로 감소함 은 확인하였다[6]. 청국장은 발효과정 동안에 isoflavonoid aglycone의 양이 유의적으로 증가되고, 이들 증가된 분획은 인슐린-자극 글루코오스를 촉진한다[21]. 따라서 본 연구에서 는 청국장 추출물의 처리에 의한 성장호르몬의 증가는 청국장 에 다량으로 함유된 이소플라본과 상호관련성이 높을 것으로 사료된다. 그러나 품종별 이소플라본의 함량증가와 발효과정 의 상관관계에서 비롯된 성장호르몬의 분비에 미치는 영향에 대한 연구가 필요할 것으로 사료된다.

또한 본 실험에서는 분비된 성장호르몬의 신호전달을 살펴 보기 위하여, 성장호르몬의 대표적인 표적세포로서, osteoblast와 hepatocyte를 사용하였다. 두가지 표적세포의 선정은 osteoblast cell인 UMR 106.01에서 성장호르몬에 의한 GHR mRNA의 발현의 증가[30]와, hepatocyte인 HepG2 세포에서 성장호르몬 자극에 의해 STAT5b 인산화와 IGF-1 발현의 증가 에 대한 연구결과에 기인한다[24].

한편 성장호르몬은 수용체에 결합 한 후, JAK 2 를 활성화 시키며 2차 전달물질로 mitogen activated protein (MAP) kinase 및 STAT을 이용하여 성장호르몬의 기능을 나타낸다 [4]. JAK는 tyrosine kinase family 중 하나이며, 성장호르몬 이 성장호르몬 수용체에 결합하면, JAK2의 활성화가 이루어 지고, STAT 단백질 등이 결합할 수 있는 자리를 형성한다 [7]. 또한 STAT5는 SH-2 도메인을 포함하는 cytoplasmic factor이며, JAK kinase cascade를 통해 tyrosyl 잔기가 인산화 되면, 세포질 내에 존재하는 STAT5가 p-STAT5와 결합하여 핵으로 이동하게 된다. 핵 안에서, p-STAT5는 DNA와 결합
하여 target 유전자의 전사를 촉진함으로써 성장과 대사작용 을 조절한다[11]. 뇌하수체 전엽 유전자, prophet of pituitary factor-1 (Prop1)의 돌연변이가 일어난 Ames dwarf mice에 서 성장호르몬은 복강 투여 후, 15 분 뒤에 부검하여 확인 한 결과, 간과 골격근에서 STAT3과 STAT5의 티로신 인산화를 유발하였다[26]. 그러나 본 실험에서는 성장호르몬을 직접 처리한 것이 아니라, 청국장으로 유도한 조건적 배양액을 처 리하였기 때문에 신호전달 반응 시간이 15 분보다 느린 것으 로 사료된다. 비록 직접적으로 성장호르몬을 투여했을 때와 반응속도는 차이가 있으나, p-STAT5가 핵으로 이동하여, 전 사를 조절함으로써, 세포의 성장을 촉진하는 기능을 관찰함 으로써 청국장에 의해 유도된 성장호르몬이 정상적으로 작 용함을 제시하고 있다.

이상의 논의로부터, 본 연구에서는 여러 가지 콩 품종을 통 해 제조된 청국장의 독성과 성장호르몬의 분비에 미치는 영향 을 분석하였으며, 그 결과 3 가지 품종이 성장호르몬의 분비를 촉진시키며, 분비된 성장호르몬이 세포성장을 촉진함을 제시 하고 있다. 이러한 결과는 청국장이 동물의 성장에 미치는 작 용기전을 규명하는 과정에 중요한 기초자료로 활용될 수 있을 것으로 사료된다.

\section{감사의 글}

본 연구는 농림수산식품기술기획평가원(111030-03)의 지원 에 의해 수행되었습니다.

\section{References}

1. Andreassen, T. T., Jorgensen, P. H., Flyvvbjerg, A., Orskov, H. and Oxlund, H. 1995. Growth hormone stimulates bone formation and strength of cortical bone in aged rats. J. Bone Miner. Res. 10, 1057-1067.

2. Anthony, M. S., Clarkson, T. B., Hughes, J. R., Morgan, T. M. and Burke, G. L. 1996. Soybean isoflavones improve cardiovascular risk factors without affecting the reproductive system of peripubertal rhesus monkey. J. Nutr. 126, 43-50.

3. Atti, K. M. 2000. The importance of growth hormone replacement therapy for bone mass in young adults with growth hormone deficiency. J. Pediatr. Endocrinol. Metab. 13, 1011-1021.

4. Campbell, G. S.1997. Growth hormone signal transduction. J. Pediatr. 131 (Suppl), S42.

5. Carter-Su, C., King, A. P., Argetsinger, L. S., Smit, L. S., Vanderkuur, J. and Campbell, G. S. 1996. Signalling pathway of GH. Endocr. J. 43(Suppl), S65-S70.

6. Cassidy, A., Bing ham, S. and Setchell, K. 1995. Biological effects of isoflavones in young women: importance of the chemical composition of soybean products. Br. J. Nutr. 74, 587-601.

7. Darnell, J. E. Jr, Kerr, I. M. and Stark, G. R. 1994. Jak-STAT 
pathways and transcriptional activation in response to IFNs and other extracellular signaling proteins. Science 264, 1415-1421.

8. Gerlier, D. and Thomasset, N. 1986. Use of MTT colorimetric assay to measure cell activation. J. Immunol. Methods 94, 57-63.

9. Herrington, J., Smit, L. S., Schwartz, J. and Carter-Su, C. 2000. The role of STAT proteins in growth hormone signaling. Oncogene 19, 2585-2597.

10. Hong, S. W., Kim, Y. J., Lee, B. K. and Chung, K. S. 2006. The bacterial biological response modifier enriched Cheonggukjang fermentation. Korea J. Food Sci. Technol. 38, 548-553.

11. Ihle, J. N. 1996. STATs: signal transducers and activators of transcription. Cell 84, 331-334.

12. Ishida, H., Uesugi, T., Hirai, K., Toda, T., Nukaya, H., Yokotsuka, K. and Tsuji, K. 1998. Preventive effects of the plant isoflavones, daidzin, and genistin, on bone loss in ovariectomized rats fed a calcium-deficient diet. Biol. Pharm Bull. 21, 62-66.

13. Kajiya, H., Takekoshi, S., Miyai, S., Ikeda, T., Kimura, S. and Osamura, R. Y. 2005. Dietary soybean enhances Pit-1 dependent pituitary hormone production in iodine deficient rats. J. Mol. Histol. 36, 265-274.

14. Kassem, M., Blum, W. and Risteli, J. 1993. Growth hormone stimulates proliferation and differentiation of normal human osteoblast-like cells in vitro. Calcif. Tissue Int. 52, 222-226.

15. Kim, J. S. 1996. Current research trends on bioactive function of soybean. Korea Soybean Digest 13, 17-24.

16. Kim, S. H., Yang, J. L. and Song, Y. S. 1999. Physiological functions of Chungkukjang. Food Indus. Nutr. 4, 40-46.

17. Kim, W. K., Choi, K. H., Kim, Y. T., Park, H. H., Choi, J. Y., Lee, Y. S., Oh, H. I., Kwon, I. B. and Lee, S. Y. 1996. Purification and characterization of a fibrinolytic enzyme produced for Bacillus sp. Strain CK 11-4 screened from Cheonggukjang. Appl. Environ. Microbiol. 62, 2482-2488.

18. Kim, Y. T., Kim, W. K. and Oh, H. I. 1995. General microbiology, physiology and metabolism Screening and identification of the fibrinolytic bacterial strain from Cheonggukjang. Korean J. Microbiol. Biotechnol. 23, 1-5.

19. Koh, J. B. 2006. Effects of Cheonggukjang on lipid metabolism in hyperlipidemic female rats. Korean J. Nutr. 39, 331-337.

20. Kwak, C. S., Kim, M. Y., Kim, S. A. and Lee, M. S. 2006. Cytotoxicity on human cancer cells and antitumorigenesis of Cheonggukjang, a fermented soybean product, im DMBA-treated rats. Korean J. Nutr. 39, 347-356.

21. Kwon, D. Y., Jang, J. S., Lee, J. E., Kim, Y. S., Shin, D. H. and Park, S. 2006. The isoflavonoid aglycone-rich fraction of chungkookjang, fermented unsalted soybeans, enhance insulin signaling and peroxisome proliferator-activated receptor-gamma activity in vitro. Biofactors 26, 245-258.

22. Lee, E. H. and Chyun, J. H. 2007. Effects of Chongkuljang intake on lipid metabolism and liver function in ethanol consumed rats. Korean J. Nutr. 40, 684-692.

23. Leung, K. C., Howe, C., Gui, L. Y., Trout, G., Veldhuis, J. D. and Ho, K. K. 2002. Physiological and pharmacological regulation of $20-\mathrm{kDa}$ growth hormone. Am J. Physiol. Endocrind. Metab. 283, 836 - 843.

24. Li, L., He, D., Wilborn, T. W., Falany, J. L. and Falany, C. N. 2009. Increased SULT1E1 activity in HepG2 hepatocytes decreases growth hormone stimulation of STAT5b phosphorylation. Steroids 74, 20-29.

25. Merz-Demlow, B. E., Duncan, A. M., Wangen, K. E., Xu, X., Carr, T. P., Phipps, W. R. and Kurzer, M. S. 2000. Soy isoflavones improve plasma lipids in normocholesterolmic, premenopausal women. Am J. Clin. Nutr. 71, 1462-1469.

26. Miquet, J. G., Muñoz, M. C., Giani, J. F., González, L., Dominici, F. P., Bartke, A., Turyn, D. and Sotelo, A. I. 2010. Ames dwarf (Prop1(df)/Prop1(df)) mice display increased sensitivity of the major GH-signaling pathways in liver and skeletal muscle. Growth Horm IGF Res. 20, 118-126.

27. Perez, F. R., Casabiell, X., Camina, J. P., Zugaza, J. L. and Casanueva, F. F. 1997. cis-unsaturated free fatty acids block growth hormone and prolactin secretion in thyrotropin-releasing hormone-stimulated GH3 cells by perturbing the function of plasma membrane integral proteins. Endocrinology 138, 264-272.

28. Potter, S. M., Baum, J. A., Teng, H., Stillman, R. J., Shay, N. F. and Erdman, J. W. Jr. 1998. Soy protein and isoflavones; Their effects on blood lipids and bone density $\mathrm{n}$ postemenopausal women. Am J. Clin. Nutr. 68, 1375-1379.

29. Shim, S. H., Lee, E. J., Kim, J. S., Kang, S. S., Ha, H., Lee, H. Y., Kim, C., Lee, J. H. and Son, K. H. 2008. Rat growth-hormone release stimulators from fenugreek seeds. Chem Biodivers 5, 1753-1761.

30. Slootweg, M. C., Swolin, D., Netelenbos, J. C., Isaksson, O. G. and Ohlsson, C. 1997. Estrogen enhances growth hormone receptor expression and growth hormone action in rat osteosarcoma cells and human osteoblast-like cells. $J$. Endocrinol. 155, 159-164.

31. Yang, J. L., Lee, S. H. and Song, Y. S. 2003. Improving effect of powders of cooked soybean and Cheonggulyang on blood pressure and lipid metabolism in spontaneously hypertentive rats. J. Korean Soc. Food Sci. Nutr. 32, 899-905.

32. Yoshizato, H., Fujikawa, T., Shibata, M., Tanaka, M. and Nakashima, K. 1999. Stimulation of growth hormone gene expression in the pituitary and brain by Panax ginseng $C$. A. MEYER. Endocr. J. 46, 85-88. 
초록 : GH3 뇌하수체 세포주로부터 성장호르몬의 분비와 성장호르몬 수용체 신호전달에 미치는 청국장 추출물의 효능

최선일 ${ }^{1}$ 김지은 ${ }^{1} \cdot$ 황인식 ${ }^{1} \cdot$ 이혜련 ${ }^{1} \cdot$ 이영주 ${ }^{1} \cdot$ 손홍주 $^{2} \cdot$ 김동섭 $^{3} \cdot$ 박규민 $^{4} \cdot$ 황대연 ${ }^{1} \star$

(부산대학교 생명자원과학대학 ${ }^{1}$ 바이오소재과학과, ${ }^{2}$ 생명환경화학과, ${ }^{3}$ 식품공학과, ${ }^{4}$ 장마을)

뇌하수체 전엽에서 성장호르몬의 생산과 분비는 세포의 분열과 분화 그리고 이동을 조절하는 몇 가지 천연물 질에 의해 유도된다. 따라서 발효과정을 통해 제조된 청국장이 성장호르몬의 대사에 미치는 영향을 평가하기 위 하여 성장호르몬 분비능과 반응성을 뇌하수체 세포와 성장호르몬 표적세포에서 관찰하였다. 6 가지 종류의 콩 품 종으로 제조된 청국장 추출물 중에서, 대원, 대풍, 태광의 3 종류 청국장 추출물은 $5 \mathrm{mg} / \mathrm{ml}$ 농도에서 $\mathrm{GH} 3$ 세포로 부터 성장호르몬의 분비를 촉진하였다. 비록 세포 생존능은 이러한 추출물에 의해 유의적인 변화가 유도되지 않 았으나, 성장호르몬의 분비량은 청국장 추출물의 농도에 의존적으로 증가하였다. 또한 성장호르몬의 표적 기관으 로부터 유래된 MG63과 HepG2 세포는 GH3로부터 수집된 조건적 배양액에 의해 유의적으로 활성화되었다. 또한 이러한 세포에서 STAT5 발현은 대원 청국장 추출물을 처리 후, 15 분 혹은 30 분부터 세포질에서 유의적으로 증가 하였으며, p-STAT5는 핵에서 30 분 혹은 60 분부터 증가하였다. 따라서 이러한 결과는 3 가지 종류의 청국장 추출 물은 성장호르몬의 분비를 촉진시키며, 청국장의 조건적 배양액은 성장호르몬 표적세포에서 신호전달을 유도함 을 제시하고 있다. 